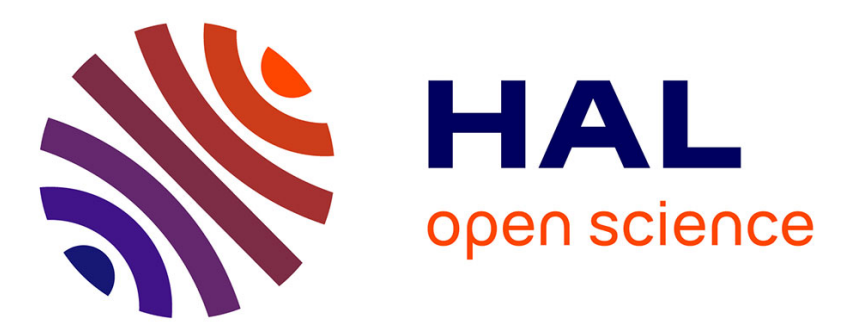

\title{
Deprotonative metalation of five-membered aromatic heterocycles using mixed lithium-zinc species
}

\author{
J.M. L'Helgoual'Ch, Anne Seggio, Floris Chevallier, M. Yonehara, Erwann
}

Jeanneau, Masanobu Uchiyama, Florence Mongin

\section{- To cite this version:}

J.M. L'Helgoual'Ch, Anne Seggio, Floris Chevallier, M. Yonehara, Erwann Jeanneau, et al.. Deprotonative metalation of five-membered aromatic heterocycles using mixed lithium-zinc species. Journal of Organic Chemistry, 2007, 73 (1), pp.177-183. 10.1021/jo7020345 . hal-00784514

\section{HAL Id: hal-00784514 \\ https://hal.science/hal-00784514}

Submitted on 5 Feb 2014

HAL is a multi-disciplinary open access archive for the deposit and dissemination of scientific research documents, whether they are published or not. The documents may come from teaching and research institutions in France or abroad, or from public or private research centers.
L'archive ouverte pluridisciplinaire HAL, est destinée au dépôt et à la diffusion de documents scientifiques de niveau recherche, publiés ou non, émanant des établissements d'enseignement et de recherche français ou étrangers, des laboratoires publics ou privés. 


\section{Deprotonative metalation of five-membered aromatic}

\section{heterocycles using mixed lithium-zinc species}

Jean-Martial L'Helgoual'ch, ${ }^{\dagger}$ Anne Seggio, ${ }^{\dagger}$ Floris Chevallier, ${ }^{\dagger}$ Mitsuhiro Yonehara ${ }^{\dagger}$

Erwann Jeanneau, ${ }^{\S}$ Masanobu Uchiyama, ${ }^{*,+}$ and Florence Mongin ${ }^{*}, \dagger$

Synthèse et ElectroSynthèse Organiques, UMR 6510 CNRS, Université de Rennes 1, Bâtiment 10A,

Case 1003, Campus Scientifique de Beaulieu, 35042 Rennes, France, The Institute of Physical and

Chemical Research, RIKEN, 2-1 Hirosawa, Wako-shi, Saitama 351-0198, Japan, and Centre de

Diffractométrie Henri Longchambon, Université Claude Bernard Lyon 1, 69622 Villeurbanne, France

florence.mongin@univ-rennes1.fr,uchi_yama@riken.jp

RECEIVED DATE (to be automatically inserted after your manuscript is accepted if required according to the journal that you are submitting your paper to)

${ }^{\dagger}$ UMR 6510 CNRS, Université de Rennes 1.

$\ddagger$ RIKEN.

${ }^{\S}$ Centre de Diffractométrie Henri Longchambon, Université Lyon 1.

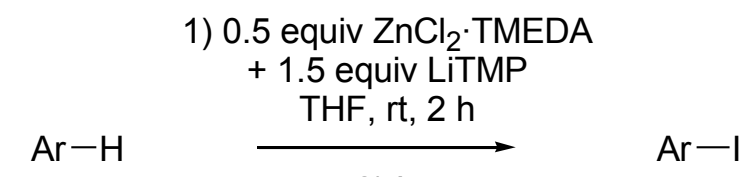

2) $I_{2}$

$\mathrm{Ar}-\mathrm{H}=$ benzoxazole, benzothiazole, benzo[b]thiophene, benzo[b]furan, $N$-Boc indole, $N$-Boc pyrrole, $N$-phenylpyrazole: $52-73 \%$ 


\begin{abstract}
:
Deprotonation of benzoxazole, benzothiazole, benzo $[b]$ thiophene, benzo $[b]$ furan, $N$-Boc protected indole and pyrrole, and $\mathrm{N}$-phenylpyrazole using an in situ mixture of $\mathrm{ZnCl}_{2} \cdot \mathrm{TMEDA}(0.5$ equiv) and lithium 2,2,6,6-tetramethylpiperidide (1.5 equiv) in THF at room temperature was described. The reaction was evidenced by trapping with iodine, regioselectively giving the expected functionalized derivatives in 52 to $73 \%$ yields. A mixture of mono- and disubstituted derivatives was obtained starting from thiazole. Cross-coupling reactions of 2-metalated benzo[b]thiophene and benzo[b]furan with heteroaromatic chlorides proved possible under palladium catalysis. A reaction pathway where the lithium amide and zinc diamide present in solution behave synergically was proposed for the deprotonation reaction, taking account of NMR and DFT studies carried out on the basic mixture.
\end{abstract}

\title{
Introduction
}

Substituted five-membered aromatic heterocycles are structural units present in many natural products and pharmaceutical synthetic intermediates. ${ }^{1}$ Among the methods used to functionalize them, ${ }^{1}$ deprotonation reactions using lithiated bases have been developed. ${ }^{2}$ This methodology often requires low temperatures and can not be used when reactive functional groups are present. In addition, unlike organoboron, organotin, organozinc and organomagnesium compounds, organolithiums can hardly be involved in cross-coupling reactions. ${ }^{3}$ Organomagnesium compounds have been prepared by deprotonation at higher temperatures. ${ }^{4}$ Nevertheless, because of the limited reactivity of the magnesium amide or diamide used to deprotonate functionalized substrates, an excess has in general to be employed to ensure good yields. ${ }^{5}$ In addition, even if the use of mixed lithium-magnesium amides seems more promising, ${ }^{6}$ it is still not extendable to very sensitive substrates. 
The deprotonation reactions of sensitive aromatics such as alkyl benzoates, ethyl thiophenecarboxylates, ethyl 2-furancarboxylate, pyridine, quinoline and isoquinoline using ${ }^{t} \mathrm{Bu}_{2} \mathrm{Zn}$ (TMP)Li (TMP = 2,2,6,6-tetramethylpiperidino) as a base were first described in $1999 .{ }^{7}$ More recently, the use of the aluminium ate base ${ }^{i} \mathrm{Bu}_{3} \mathrm{Al}(\mathrm{TMP}) \mathrm{Li}$ and the copper ate bases $\mathrm{R}(\mathrm{TMP}) \mathrm{Cu}(\mathrm{CN}) \mathrm{Li}_{2}$ $(\mathrm{R}=$ alkyl, aryl, or TMP) have been developed in order to generate functionalized aromatic compounds including heterocycles. ${ }^{8}$ The reactions performed in tetrahydrofuran (THF) proved to be chemoselective, but require 1 or 2 equiv of base. ${ }^{9}$

Several examples of deprotonation using lithium amidozincates in hexane have been reported by Mulvey since $2005 .^{10}$ The term alkali-metal-mediated zincation has been introduced to depict these reactions because the reactivity ("synergy") exhibited by the zincates can not be attained by the homometallic compounds on their own. ${ }^{11}$

Herein, we report a new chemoselective deprotonation tool for regio-controlled functionalization of five-membered aromatic heterocycles using a basic mixture obtained from a lithium base and TMEDAchelated zinc chloride.

\section{Results and Discussion}

To develop new chemoselective deprotonation reactions of five-membered aromatic heterocycles, our approach capitalizes on the high chemoselectivity of organozincate reagents, which allows flexible design and fine-tuning by modifying the ligation environment. In the initial screening of suitable zincates, benzoxazole (1) was selected as a model substrate because this substrate can be readily metalated by alkyllithiums, but the 2-lithiated species is well-known to be in equilibrium with the corresponding lithium phenolate, even at extremely low temperature. ${ }^{12}$ We therefore focused on the stability of intermediary aromatic zincates (relative to their lithium analogues) which is well-known to

prevent from subsequent rearrangement ${ }^{13}$ or side-reactions. ${ }^{14} \mathrm{We}$ assumed that it might allow the 
regioselective zincation of five-membered aromatic heterocycles and the isolation of 2-zincate intermediates without any successive side-reactions.

Previous NMR studies on 2-metallo benzoxazole have shown the equilibrium was completely on the side of the open isomer with lithium, whereas transmetalation to the organozinc derivative favored the ring closure. ${ }^{15}$ Then, we performed a preliminary DFT study on the stability of 2-metallo benzoxazoles and their rearrangement pathways by means of the B3LYP/6-31+G* method. Figure 1 shows the energy changes for each path, and the geometries of the transition states, intermediates and products. While the transition state (TS) and the product (PD) of 2-lithio derivatives were kinetically and thermodynamically stable, those of the 2-zincio compounds were found to be more unstable compared with 2-zincio reactant (RT), which was consistent with the experimental observations. These big energetic changes by the difference of metal species prompted us to further survey on whether the zincate bases could be used for chemoselective metalation of aromatic heterocycles.
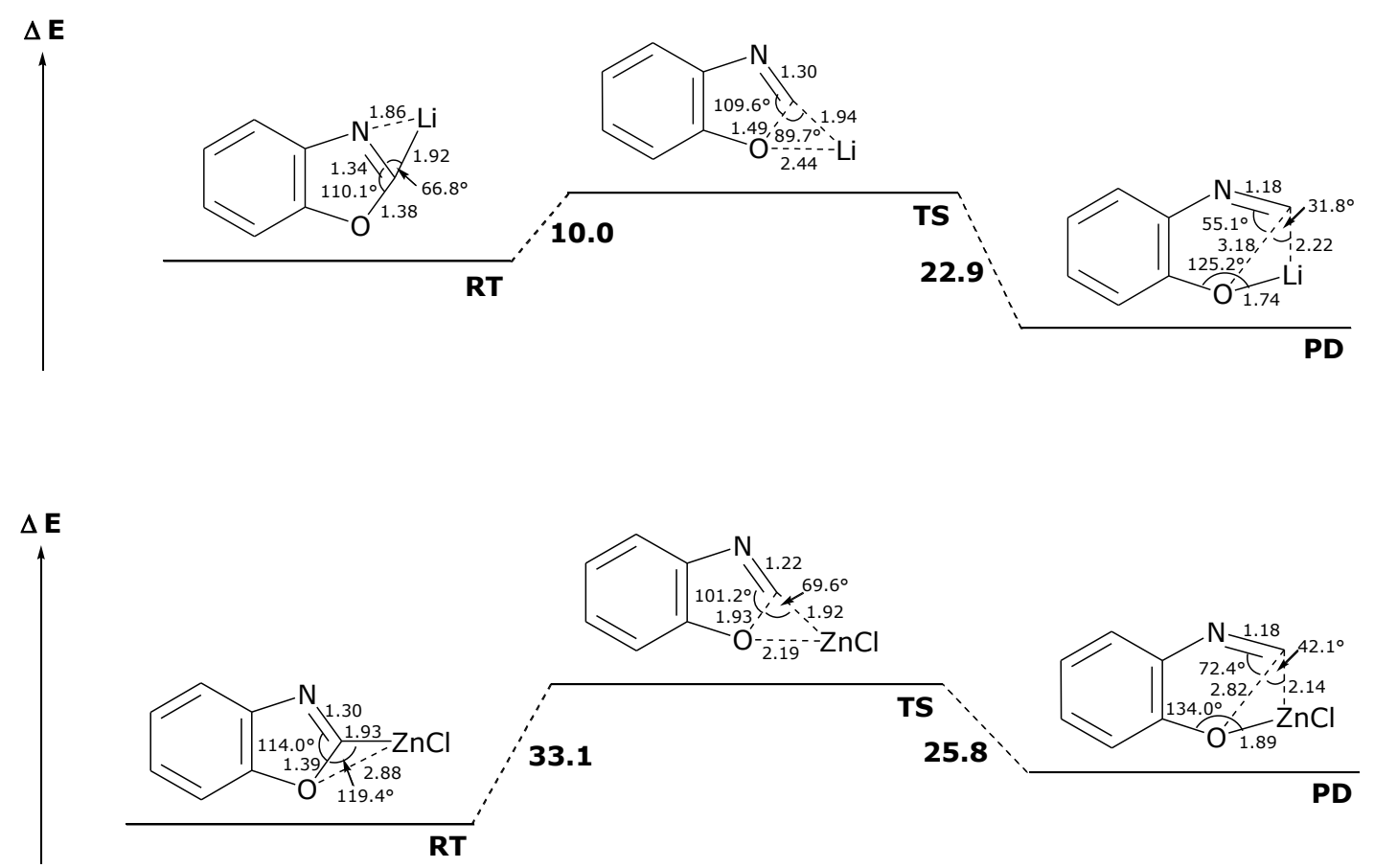

FIGURE 1. Calculated structures for the reactants, transition states and products, and energy changes. Bond lengths and energy changes at the B3LYP/6-31+G* level are shown in $\AA$ and kcal/mol, respectively. 
The deprotonation reaction of $\mathbf{1}$ was then examined using various zincate reagents (Table 1). The addition of one molar equiv (per lithium) of TMEDA or THF to a bulk nonpolar hydrocarbon in order to increase the opportunity for crystal growth proved to favor the deprotonation reactions of $N, N$ diisopropylcarboxamide $^{10 \mathrm{~b}, \mathrm{c}}$ and anisole ${ }^{10 \mathrm{~d}}$ using lithium amidozincates. We therefore decided to prepare bases from $\mathrm{ZnCl}_{2} \cdot \mathrm{TMEDA},{ }^{16}$ much less hygroscopic than $\mathrm{ZnCl}_{2}$, and 3 (or 4) equiv of alkyllithium or lithium dialkylamide, and to study their ability to deprotonate benzoxazole (1) (Table 1).

TABLE 1. Deprotonation of benzoxazole (1) using in situ prepared mixtures of $\mathrm{ZnX}_{2} \cdot \mathrm{TMEDA}$ and 3 (or 4) equiv of alkyllithium or lithium dialkylamide

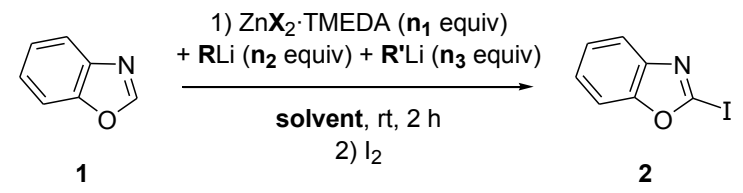

\begin{tabular}{lllllllll}
\hline entry & $\mathbf{X}$ & $\mathbf{n}_{1}$ & $\mathbf{R}$ & $\mathbf{n}_{2}$ & $\mathbf{R}^{\prime}$ & $\mathbf{n}_{3}$ & solvent yield (\%) \\
\hline 1 & $\mathrm{Cl}$ & 1.0 & $\mathrm{Me}$ & 3.0 & - & - & $\mathrm{THF}$ & 28 \\
2 & $\mathrm{Cl}$ & 1.0 & $\mathrm{Bu}$ & 3.0 & - & - & $\mathrm{THF}$ & 10 \\
3 & $\mathrm{Cl}$ & 1.0 & $\mathrm{Bu}$ & 4.0 & - & - & $\mathrm{THF}$ & 32 \\
4 & $\mathrm{Cl}$ & 1.0 & $\mathrm{Bu}$ & 2.0 & $\mathrm{TMP}$ & 1.0 & $\mathrm{THF}$ & 35 \\
5 & $\mathrm{Cl}$ & 1.0 & ${ }^{5} \mathrm{Bu}$ & 2.0 & $\mathrm{TMP}$ & 1.0 & $\mathrm{THF}$ & 38 \\
6 & $\mathrm{Cl}$ & 1.0 & $\mathrm{Me}$ & 2.0 & $\mathrm{TMP}$ & 1.0 & $\mathrm{THF}$ & 44 \\
7 & $\mathrm{Cl}$ & 0.50 & $\mathrm{TMP}$ & 1.5 & - & - & $\mathrm{THF}$ & 57 \\
8 & $\mathrm{Cl}$ & 0.33 & $\mathrm{TMP}$ & 1.0 & - & - & $\mathrm{THF}$ & 60 \\
9 & $\mathrm{Cl}$ & 0.40 & $\mathrm{TMP}$ & 1.2 & - & - & $\mathrm{THF}$ & 55 \\
10 & $\mathrm{Cl}$ & 0.40 & $\mathrm{TMP}$ & 1.2 & - & - & hexane & 55 \\
11 & $\mathrm{Br}$ & 0.33 & $\mathrm{TMP}$ & 1.0 & - & - & $\mathrm{THF}$ & 58 \\
\hline
\end{tabular}

The first experiments were carried out with bases obtained by mixing 1 equiv of $\mathrm{ZnCl}_{2} \cdot \mathrm{TMEDA}$ and 3 equiv of methyl- or butyllithium, and assumed to be lithium trimethylzincate and lithium tributylzincate, respectively. ${ }^{17}$ When used in THF at room temperature for $2 \mathrm{~h}$, these mixed Li-Zn compounds hardly 
metalated benzoxazole (1), giving the 2-substituted derivative $\mathbf{2}$ in low yields of 28 and $10 \%$, respectively, after trapping with iodine (Entries 1 and 2). Since dilithium tetraalkylzincates have been shown to exhibit a higher reactivity compared to lithium trialkylzincates in various reactions including halogen-metal exchange, ${ }^{18}$ we decided to use 4 equiv of butyllithium instead of 3 . Admittedly the yield was higher using 4 equiv (32\%, entry 3) instead of 3, but still low. Considering the preference for dialkylamino over alkyl transfer in THF, ${ }^{7 \mathrm{~d}}$ we then decided to replace one of the butyl group by a TMP. The heteroleptic base was prepared by successively adding 2 equiv of butyllithium and 1 equiv of LiTMP to a solution of $\mathrm{ZnCl}_{2} \cdot \mathrm{TMEDA}$. Since the base prepared similarly by successively adding 2 equiv of tert-butyllithium and 1 equiv of LiTMP to a solution of $\mathrm{ZnCl}_{2}$ in THF proved to be ${ }^{t} \mathrm{Bu}_{2} \mathrm{Zn}(\mathrm{TMP}) \mathrm{Li},{ }^{7 \mathrm{~d}}$ we assumed the base we prepared was a zincate. ${ }^{19}$ Using the latter (1 equiv) in THF at room temperature for $2 \mathrm{~h}$ to metalate benzoxazole (1) resulted in a moderate $35 \%$ yield of the iodide 2 after interception with iodine (Entry 4). Similar bases were prepared by replacing butyllithium either by sec-butyllithium (Entry 5) or methyllithium (Entry 6). ${ }^{20}$ Metalation attempts resulted in slightly improved yields of 38 and 44\%, respectively. The moderate $44 \%$ yield obtained by employing $\mathrm{Me}_{2} \mathrm{Zn}$ (TMP)Li was partly attributed to the conversion step to the iodo compound $\mathbf{2}$ and its isolation; ${ }^{21}$ indeed, monitoring the reaction by ${ }^{1} \mathrm{H}$ NMR indicated a complete conversion after $2 \mathrm{~h} .{ }^{22}$ This result was not satisfying however since 1 equiv of zincate is required. It was therefore decided to replace all the alkyl groups by TMP in order to reduce the amount of base. The experiment carried out with 0.5 equiv of $\mathrm{ZnCl}_{2} \cdot$ TMEDA and 1.5 equiv of LiTMP under the reaction conditions used before furnished the iodide 2 in $57 \%$ yield (Entry 7). A similar result was obtained using $1 / 3$ equiv of $\mathrm{ZnCl}_{2} \cdot \mathrm{TMEDA}$ and 1 equiv of LiTMP (Entry 8, 60\% yield), with a ${ }^{1} \mathrm{H}$ NMR monitoring indicating a 90\% conversion after 2 h. ${ }^{23}$ Examples of efficient deprotonation using lithium zincates being reported in hexane containing one molar equivalent of TMEDA, ${ }^{10 \mathrm{~b}-\mathrm{d}}$ experiments using hexane instead of THF were performed, and ended in similar yields (Entries 9 and 10). It was finally decided to see the influence of the zinc source on the result of the reaction. It was found that zinc bromide (Entry 11, 58\%) and zinc chloride (Entry 8, 60\%) 
could be equally employed.

In order to obtain additional information about the active species of a basic mixture obtained from a THF solution of $1 / 3$ equiv of $\mathrm{ZnCl}_{2} \cdot$ TMEDA and 1 equiv of LiTMP, its NMR and DFT studies were then carried out. Since (TMP) $)_{2}$ Zn (1 equiv) and LiTMP (1 equiv) give lower conversions when used separately under the same reaction conditions, both of them play a role in the deprotonation mechanism. But even if alkali-metal triamidozincates have been evidenced, ${ }^{24}$ sterically hindered lithium dialkylamide and diamidozinc (e. g. $\mathrm{LiN}\left(\mathrm{SiMe}_{3}\right)_{2}$ and $\left.\mathrm{Zn}\left[\mathrm{N}\left(\mathrm{SiMe}_{3}\right)_{2}\right]_{2}\right)$ rarely stabilize as a lithium triamidozincate. ${ }^{25}$ In addition, the in situ prepared 1:3 mixture of $\mathrm{ZnCl}_{2} \cdot$ TMEDA and LiTMP in THF was studied by NMR, and the analysis of the ${ }^{13} \mathrm{C}$ spectra revealed that the main species in solution were LiTMP and $(\mathrm{TMP})_{2} \mathrm{Zn}^{26}{ }^{26}$ This was confirmed by the B3LYP-calculated equilibrium between LiTMP and $(\mathrm{TMP})_{2} \mathrm{Zn}$ on one side and $(\mathrm{TMP})_{3} \mathrm{ZnLi}$ on the other side (Scheme 1), which is interestingly sharp contrast to dialkylamidozincate (TMP-zincates). ${ }^{7 \mathrm{a}, 7 \mathrm{~d}, 10 \mathrm{a}, 10 \mathrm{~b}}$

SCHEME 1. Bond lengths at the B3LYP/6-31G* level are shown in $\AA$

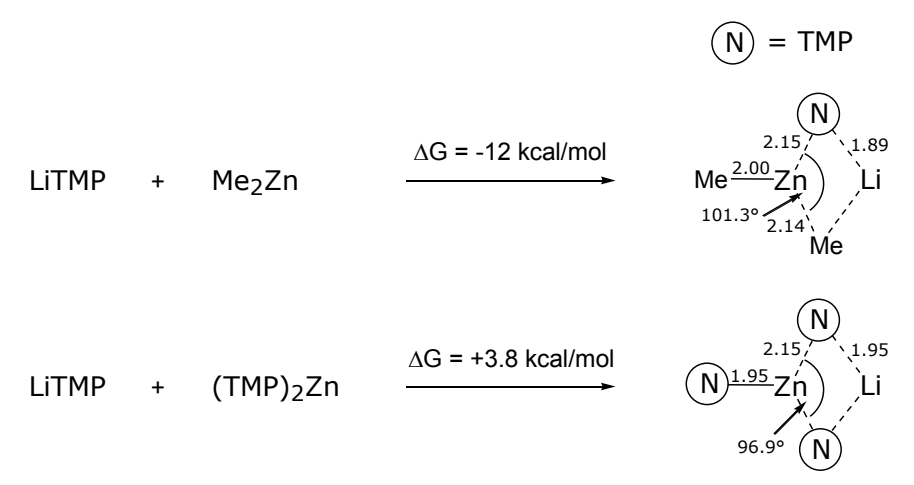

On this basis, one can assume a reaction pathway where the deprotonation proceeds with LiTMP, and the resultant aryllithium intermediate converts smoothly and quickly by in situ trapping with (TMP) $2 \mathrm{Zn}$ (or ArZnTMP) to the more stabilized arylzinc species, as depicted in Scheme 2. Further studies on a structural study of this basic mixture and a mechanistic investigation of this novel metalation are in 
progress with the help of ab initio calculations and spectroscopies. ${ }^{27}$

SCHEME 2. Proposed pathway for the metalation of benzoxazole (1) using an in situ prepared 1:3 mixture of $\mathrm{ZnCl}_{2} \cdot \mathrm{TMEDA}^{\mathrm{T}} \mathrm{and} \mathrm{LiTMP}$
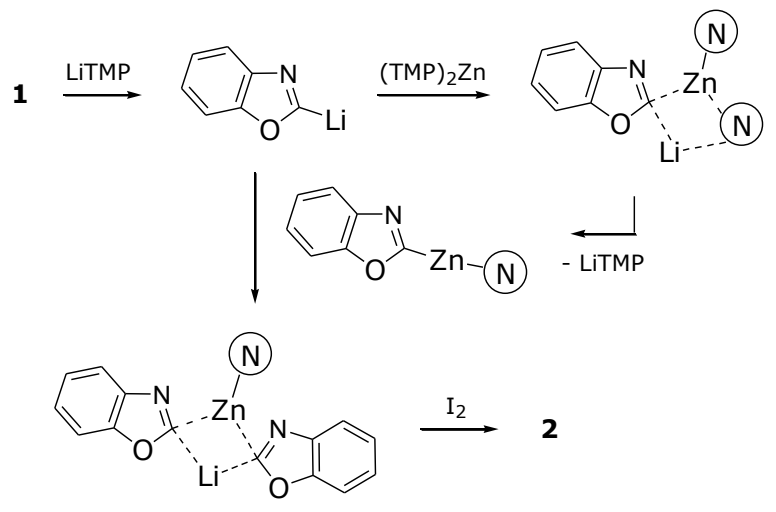

Having obtained the active species and mechanism that is likely to be experimentally relevant, metalation of other substrates using the in situ prepared mixture of 0.5 equiv of $\mathrm{ZnCl}_{2} \cdot \mathrm{TMEDA}$ and 1.5 equiv of LiTMP was attempted to evaluate the scope of the reaction under the reaction conditions used before (Table 2).

Lithiation of benzothiazole (3) has been reported using phenyl- and butyllithium in ethers at very low temperatures. ${ }^{28}$ When treated with the in situ prepared mixture of 0.5 equiv of $\mathrm{ZnCl}_{2} \cdot$ TMEDA and 1.5 equiv of LiTMP, metalation also occurred at the 2 position, as demonstrated by quenching with iodine to afford the iodide 4 in a medium 52\% yield (Entry 2).

Benzo[b]thiophene (5) can be easily metalated using butyllithium in THF at $0{ }^{\circ} \mathrm{C}^{29}$ Using our basic mixture furnished after trapping with iodine the expected derivative 6 in $73 \%$ yield. A similar result was observed from benzo[b]furan (7). The latter has previously been deprotonated using tert-butyllithium in diethyl ether at $-78{ }^{\circ} \mathrm{C} .{ }^{30}$ The metalation with the in situ prepared basic mixture was attempted using both 0.5 equiv of $\mathrm{ZnCl}_{2} \cdot$ TMEDA and 1.5 equiv of LiTMP, and $1 / 3$ equiv of $\mathrm{ZnCl}_{2} \cdot$ TMEDA and 1 equiv of LiTMP without any important change (69 and $64 \%$ yields of 8 , respectively).

We next turned to $N$-Boc indole (9). The lithiation of the latter has been described using tert- 
butyllithium in THF at $-75{ }^{\circ} \mathrm{C} .{ }^{31}$ Our method allowed the metalation to take place at room temperature, the iodide 10 being isolated in 67\% yield. Whereas tert-butyllithium proved not suitable, LiTMP can be used at $-80{ }^{\circ} \mathrm{C}$ in THF for the deprotonation of $N$-Boc pyrrole (11) ${ }^{31}$ No degradation was observed using our procedure, and the iodide $\mathbf{1 2}$ was given in $68 \%$ yield.

TABLE 2. Deprotonation of 5-membered aromatic heterocycles using the 1:3 in situ prepared mixture of $\mathrm{ZnCl}_{2} \cdot \mathbf{T M E D A}$ and LiTMP

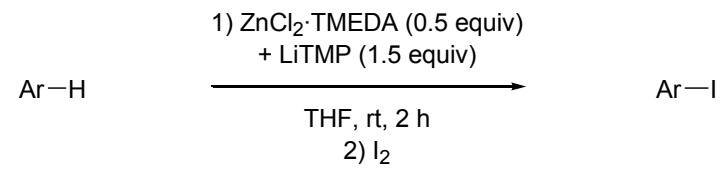

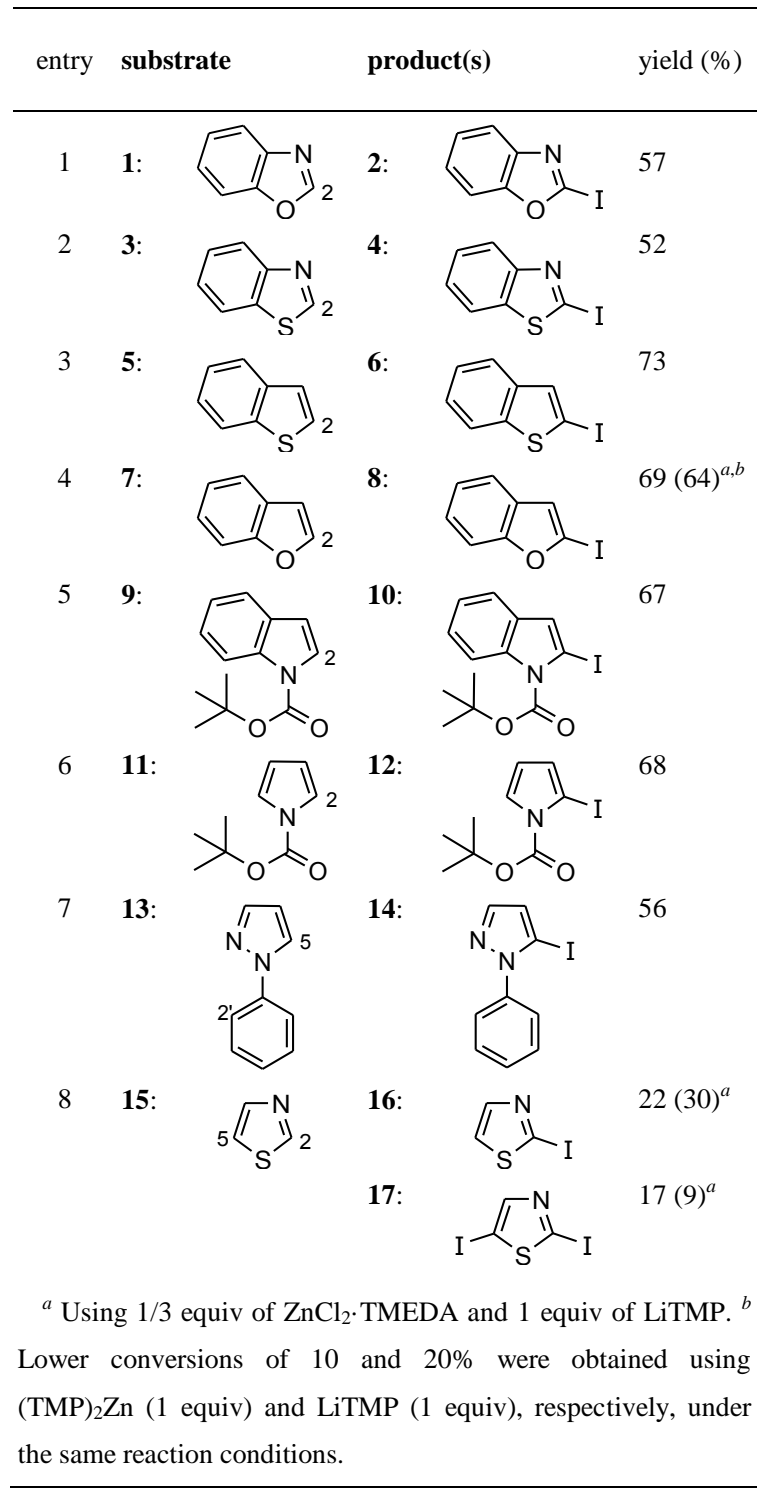


1-Phenylpyrazole (13) has been metalated using butyllithium at $-65{ }^{\circ} \mathrm{C} .{ }^{32}$ In diethyl ether, substitution occurs in the 5- and 2' positions in a ratio of about 4:1. Reaction carried out at room temperature using 0.5 equiv of $\mathrm{ZnCl}_{2} \cdot \mathrm{TMEDA}$ and 1.5 equiv of LiTMP provided the iodide $\mathbf{1 4}$ in $56 \%$ yield after electrophilic trapping.

Lithiation of thiazole (15) has been reported using butyllithium in diethyl ether at very low temperatures. ${ }^{28 a, 33}$ When treated with the mixture of 0.5 equiv of $\mathrm{ZnCl}_{2} \cdot$ TMEDA and 1.5 equiv of LiTMP in THF at room temperature for $2 \mathrm{~h}$, both the monoiodide $\mathbf{1 6}$ and the diiodide $\mathbf{1 7}$ were obtained after interception with iodine ( 22 and $17 \%$, respectively). Reducing the amount of base to $1 / 3$ equiv of $\mathrm{ZnCl}_{2} \cdot$ TMEDA and 1 equiv of LiTMP allowed to favor the formation of the monoiodo derivative $\mathbf{1 6}$ (30\%) over the diiodo 17 (9\%). ${ }^{34}$ The formation of dizincated arenes has been recently reported in the course of deprotonation reactions using a zincate: naphthalene was dimetalated at both 2 and 6 positions, ${ }^{35}$ and benzene at both 1 and 4 positions, ${ }^{36}$ when treated with ${ }^{t} \mathrm{Bu}_{2} \mathrm{Zn}(\mathrm{TMP}) \mathrm{Na} \cdot \mathrm{TMEDA}$ in hexane. Whereas the generation of dilithiums and disodiums is generally precluded by using a stoichiometric amount of base in a solvent of sufficient polarity such as $\mathrm{THF}^{37}$ the dizincated derivatives are still present after long reaction times, a result that could be attributed to their relative stability compared to the corresponding bis(alkali metal) compounds.

Subsequent cross-coupling of 2-metalated substrates was then considered in order to get bis(heterocycles). Reactions of 2-deprotonated benzo[b]thiophene and benzo[b]furan were attempted under palladium catalysis using 1,1'-bis(diphenylphosphino)ferrocene (dppf) as ligand. ${ }^{38}$ When the intermediates were subjected to reaction with 2-chloropyridine and 2,4-dichloropyrimidine, respectively, in THF at $55^{\circ} \mathrm{C}$, the bis(heterocycles) $\mathbf{1 8}$ and $\mathbf{1 9}$ were isolated in 67 and $49 \%$ yields (Scheme 3). 


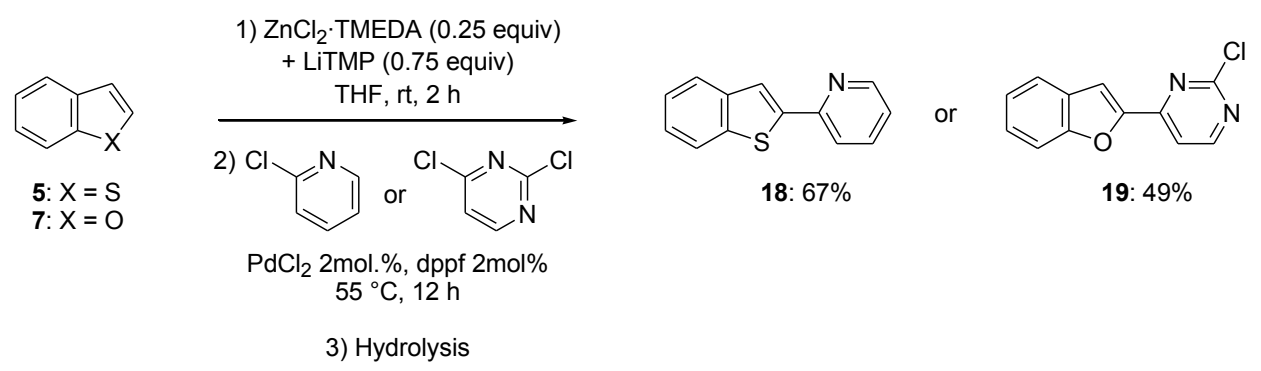

\section{Conclusion}

Activation of organometallic compounds in order to get more efficient and chemoselective bases for the deprotonation of sensitive substrates such as aromatic heterocycles is a challenging area. Our approach is based on the synergy exhibited by a mixture of (TMP) $)_{2} \mathrm{Zn}(0.5$ equiv) and LiTMP (0.5 equiv), in situ prepared from LiTMP and $\mathrm{ZnCl}_{2} \cdot \mathrm{TMEDA}$ in a 3:1 ratio. The reaction could proceed by metalation with LiTMP, stabilization of the deprotonated aromatic by trapping with (TMP) $2 \mathrm{Zn}$ (or ArZnTMP), and regeneration of the deprotonating species from sterically congested zincate intermediates. The main advantage of the method developed is the relative stability of the organometallic species formed, allowing cross-coupling reactions to be performed without transmetalation to more stable organometallics. Indeed, whereas hydrogen-lithium exchange of aromatic heterocycles has often to be performed at low temperature in order to prevent side nucleophilic addition, the protocol here described can be conducted at room temperature. The method could find synthetic applications in the deprotonation of aromatic heterocycles including sensitive substrates. ${ }^{39}$

\section{Experimental Section}

General procedure 1 for the deprotonation-iodation of heterocycles. To a stirred, cooled $\left(0{ }^{\circ} \mathrm{C}\right)$ 
solution of 2,2,6,6-tetramethylpiperidine $(1.1 \mathrm{~mL}, 6.0 \mathrm{mmol})$ in THF $(5 \mathrm{~mL})$ were successively added BuLi (about 1.6 M hexanes solution, $6.0 \mathrm{mmol}$ ) and, 5 min later, $\mathrm{ZnCl}_{2} \cdot \mathrm{TMEDA}^{17}(0.50 \mathrm{~g}, 2.0 \mathrm{mmol})$. The mixture was stirred for $15 \mathrm{~min}$ at $0{ }^{\circ} \mathrm{C}$ before introduction of the substrate $(4.0 \mathrm{mmol})$ at $10{ }^{\circ} \mathrm{C}$. After $2 \mathrm{~h}$ at room temperature, a solution of $\mathrm{I}_{2}(1.5 \mathrm{~g}, 6.0 \mathrm{mmol})$ in THF $(10 \mathrm{~mL})$ was added. The mixture was stirred overnight before addition of an aq saturated solution of $\mathrm{Na}_{2} \mathrm{~S}_{2} \mathrm{O}_{3}(4 \mathrm{~mL})$ and extraction with EtOAc $(3 \times 20 \mathrm{~mL})$. The combined organic layers were dried over $\mathrm{MgSO}_{4}$, filtered and concentrated under reduced pressure.

2-Iodobenzoxazole (2). 2 was obtained according to the general procedure 1 from benzoxazole (1, $0.48 \mathrm{~g}$ ) and isolated after purification by chromatography on silica gel (eluent: heptane/AcOEt: 90/10) as a pale yellow powder, which rapidly turns to brown upon standing $(0.56 \mathrm{~g}, 57 \%) . \mathrm{mp} 86-90{ }^{\circ} \mathrm{C}(\mathrm{dec}) .{ }^{1} \mathrm{H}$ $\operatorname{NMR}\left(\mathrm{CDCl}_{3}\right): \delta$ 7.26-7.31 (m, 2H), 7.49-7.53 (m, 1H), 7.65-7.69 (m, 1H). ${ }^{13} \mathrm{C} \mathrm{NMR}\left(\mathrm{CDCl}_{3}\right): \delta 109.2$, $109.9,118.9,124.4,125.1,142.3,153.7$. These values are consistent with the literature. ${ }^{40}$

2-Iodobenzothiazole (4). 4 was obtained according to the general procedure 1 from benzothiazole (3, $0.54 \mathrm{~g}, 0.44 \mathrm{~mL}$ ) and isolated after purification by chromatography on silica gel (eluent: heptane/AcOEt: $80 / 20)$ as a yellow powder $(0.54 \mathrm{~g}, 52 \%) . \mathrm{mp} 78-82{ }^{\circ} \mathrm{C}$ dec. ${ }^{1} \mathrm{H}$ NMR $\left(\mathrm{CDCl}_{3}\right): \delta 7.35-7.49(\mathrm{~m}, 2 \mathrm{H})$, 7.83-7.87 (m, 1H), 8.01-8.06 (m, 1H). ${ }^{13} \mathrm{C} \mathrm{NMR}\left(\mathrm{CDCl}_{3}\right): \delta 105.8,120.6,122.7,125.8,126.5,139.3$, 154.4. These values are consistent with the literature. ${ }^{41}$

2-Iodobenzo $[\boldsymbol{b}]$ thiophene (6). 6 was obtained according to the general procedure 1 from benzo $[b]$ thiophene $(5,0.54 \mathrm{~g})$ and isolated after purification by chromatography on silica gel (eluent: heptane) as a pale yellow powder $(0.76 \mathrm{~g}, 73 \%)$. mp $64{ }^{\circ} \mathrm{C}\left(1 \mathrm{it} .{ }^{42} 64-65{ }^{\circ} \mathrm{C}\right) .{ }^{1} \mathrm{H}$ NMR $\left(\mathrm{CDCl}_{3}\right): \delta 7.41-$ $7.45(\mathrm{~m}, 2 \mathrm{H}), 7.64(\mathrm{~s}, 1 \mathrm{H}), 7.81-7.92(\mathrm{~m}, 2 \mathrm{H}) .{ }^{13} \mathrm{C} \mathrm{NMR}\left(\mathrm{CDCl}_{3}\right): \delta 79.3,121.3,122.4,124.5,124.6$, 133.9, 140.9, 144.5. These values are consistent with the literature. ${ }^{43}$ HRMS: calcd for $\mathrm{C}_{8} \mathrm{H}_{5} \mathrm{IS}\left(\mathrm{M}^{+*}\right)$ 259.9157, found 259.9165. Anal. Calcd for $\mathrm{C}_{8} \mathrm{H}_{5} \mathrm{IS}$ (260.09): C, 36.94; H, 1.94; S, 12.33. Found: C, $36.90 ; \mathrm{H}, 1.95 ; \mathrm{S}, 12.28$.

2-Iodobenzo[b]furan (8). 8 was obtained according to the general procedure 1 from benzo[b]furan ( 7 , 
$0.47 \mathrm{~g}, 0.44 \mathrm{~mL}$ ) and isolated after purification by chromatography on silica gel (eluent: heptane) as a yellow oil $(0.67 \mathrm{~g}, 69 \%) .{ }^{1} \mathrm{H}$ NMR $\left(\mathrm{CDCl}_{3}\right): \delta 6.96(\mathrm{~s}, 1 \mathrm{H}), 7.20-7.24(\mathrm{~m}, 2 \mathrm{H}), 7.46-7.54(\mathrm{~m}, 2 \mathrm{H}) .{ }^{13} \mathrm{C}$ $\operatorname{NMR}\left(\mathrm{CDCl}_{3}\right): \delta 96.0,110.9,117.3,119.8,123.2,124.3,129.3,158.3$. These values are consistent with the literature. ${ }^{44}$ HRMS: calcd for $\mathrm{C}_{8} \mathrm{H}_{5} \mathrm{IO}\left(\mathrm{M}^{+\bullet}\right)$ 243.9385, found 243.9370 .

$N$-Boc-2-iodoindole (10). 10 was obtained according to the general procedure 1 from $N$-Boc-indole (9, $0.87 \mathrm{~g}, 0.81 \mathrm{~mL}$ ) and isolated after purification by chromatography on silica gel (eluent: heptane $\left./ \mathrm{CH}_{2} \mathrm{Cl}_{2}: 30 / 70\right)$ as a pale yellow oil $(0.94 \mathrm{~g}, 68 \%) .{ }^{1} \mathrm{H} \mathrm{NMR}\left(\mathrm{CDCl}_{3}\right): \delta 1.77(\mathrm{~s}, 9 \mathrm{H}), 7.01(\mathrm{~s}$, 1H), 7.22-7.30 (m, 2H), $7.48(\mathrm{dd}, 1 \mathrm{H}, J=7.8$ and 2.0), $8.17(\mathrm{~d}, 1 \mathrm{H}, J=7.2)$. These values are consistent with the literature. ${ }^{45}{ }^{13} \mathrm{C}$ NMR $\left(\mathrm{CDCl}_{3}\right): \delta 28.3(3 \mathrm{C}), 74.9,85.2,115.4,119.4,121.9,122.8,124.2$, 131.1, 137.5, 149.2. HRMS: calcd for $\mathrm{C}_{13} \mathrm{H}_{14} \mathrm{INO}_{2}\left(\mathrm{M}^{+\bullet}\right)$ 343.0069, found 343.0070. Anal. Calcd for $\mathrm{C}_{13} \mathrm{H}_{14} \mathrm{INO}_{2}$ (343.16): C, 45.50; H, 4.11; N, 4.08. Found: C, 45.47; H, 4.10; N, 4.16.

$N$-Boc-2-iodopyrrole (12). 12 was obtained according to the general procedure 1 from $N$-Boc-pyrrole (11, $0.67 \mathrm{~g}, 0.67 \mathrm{~mL}$ ) and isolated after purification by chromatography on silica gel (eluent: heptane $/ \mathrm{CH}_{2} \mathrm{Cl}_{2}: 80 / 20$ to $\left.30 / 70\right)$ as a pale yellow oil $(0.79 \mathrm{~g}, 67 \%) .{ }^{1} \mathrm{H} \mathrm{NMR}\left(\mathrm{CDCl}_{3}\right): \delta 1.52(\mathrm{~s}, 9 \mathrm{H})$, $6.08(\mathrm{t}, 1 \mathrm{H}, J=3.4), 6.43(\mathrm{dd}, 1 \mathrm{H}, J=3.4$ and 1.8$), 7.30(\mathrm{dd}, 1 \mathrm{H}, J=3.6$ and 2.0$)$. These values are consistent with the literature. ${ }^{46}{ }^{13} \mathrm{C} \mathrm{NMR}\left(\mathrm{CDCl}_{3}\right): \delta 27.9(3 \mathrm{C}), 63.1,84.6,113.5,124.8,125.4,147.9$.

5-Iodo-1-phenylpyrazole (14). ${ }^{47} 14$ was obtained according to the general procedure 1 from 1phenylpyrazole $(13,0.58 \mathrm{~g}, 0.53 \mathrm{~mL})$ and isolated after purification by chromatography on silica gel (eluent: heptane) as a pale brown powder $(0.60 \mathrm{~g}, 56 \%) . \mathrm{mp} 82-88{ }^{\circ} \mathrm{C} .{ }^{1} \mathrm{H} \mathrm{NMR}\left(\mathrm{CDCl}_{3}\right): \delta 6.63(\mathrm{~d}, 1 \mathrm{H}$, $J=1.6), 7.46-7.51(\mathrm{~m}, 5 \mathrm{H}), 7.69(\mathrm{~d}, 1 \mathrm{H}, J=1.4) .{ }^{13} \mathrm{C} \mathrm{NMR}\left(\mathrm{CDCl}_{3}\right): \delta 80.8,117.6,126.4(2 \mathrm{C}), 128.8$, $129.0(2 \mathrm{C}), 140.3,142.8$.

2-Iodothiazole (16). 16 was obtained according to the general procedure 1 from thiazole $(\mathbf{1 5}, 0.34 \mathrm{~g}$, $0.28 \mathrm{~mL}$ ) and isolated after purification by chromatography on silica gel (eluent: heptane/AcOEt: 90/10) as a yellow-orange oil $(0.19 \mathrm{~g}, 22 \%) .{ }^{1} \mathrm{H}$ NMR $\left(\mathrm{CDCl}_{3}\right): \delta 7.34(\mathrm{~d}, 1 \mathrm{H}, J=3.4), 7.62(\mathrm{~d}, 1 \mathrm{H}, J=3.4)$. 
These values are consistent with the literature. ${ }^{5 f}{ }^{13} \mathrm{C}$ NMR $\left(\mathrm{CDCl}_{3}\right): \delta 100.0,124.8,144.3$. 2,5-

Diiodothiazole 17 was isolated similarly as a yellow powder $(0.23 \mathrm{~g}, 17 \%)$. mp $106-110{ }^{\circ} \mathrm{C}\left(1 \mathrm{it} .{ }^{48} 103-\right.$ $\left.105{ }^{\circ} \mathrm{C}\right) .{ }^{1} \mathrm{H} \mathrm{NMR}\left(\mathrm{CDCl}_{3}\right): \delta 7.61(\mathrm{~s}, 1 \mathrm{H}) .{ }^{13} \mathrm{C} \mathrm{NMR}\left(\mathrm{CDCl}_{3}\right): \delta 74.8,104.0,152.9$.

General procedure 2 for the deprotonation-cross-coupling of heterocycles. To a stirred, cooled (0 $\left.{ }^{\circ} \mathrm{C}\right)$ solution of 2,2,6,6-tetramethylpiperidine $(1.1 \mathrm{~mL}, 6.0 \mathrm{mmol})$ in THF $(5 \mathrm{~mL})$ were successively added BuLi (about 1.6 $\mathrm{M}$ hexanes solution, $6.0 \mathrm{mmol})$ and, $5 \mathrm{~min}$ later, $\mathrm{ZnCl}_{2} \cdot \mathrm{TMEDA}^{17}(0.50 \mathrm{~g}, 2.0$ mmol). The mixture was stirred for $15 \mathrm{~min}$ at $0{ }^{\circ} \mathrm{C}$ before introduction of the substrate $(8.0 \mathrm{mmol})$ at 10 ${ }^{\circ} \mathrm{C}$. After $2 \mathrm{~h}$ at room temperature, the heterocyclic chloride $(6.0 \mathrm{mmol}), \mathrm{PdCl}_{2}(28 \mathrm{mg}, 0.16 \mathrm{mmol})$ and dppf $(89 \mathrm{mg}, 0.16 \mathrm{mmol})$ were added to the mixture, which was stirred for $12 \mathrm{~h}$ at $55^{\circ} \mathrm{C}$. The mixture was cooled before addition of water $(0.5 \mathrm{~mL})$ and AcOEt $(100 \mathrm{~mL})$, drying over $\mathrm{MgSO}_{4}$ and removal of the solvents under reduced pressure.

2-(2-Benzo[b]thienyl)pyridine (18). 18 was obtained according to the general procedure 2 from benzo[b]thiophene $(5,1.1 \mathrm{~g})$ and 2-chloropyridine $(0.68 \mathrm{~g}, 0.57 \mathrm{~mL})$, and isolated after purification by chromatography on silica gel (eluent: heptane $/ \mathrm{CH}_{2} \mathrm{Cl}_{2}: 50 / 50$ to $\left.30 / 70\right)$ as a white powder (0.85 g, 67\%). $\operatorname{mp} 126{ }^{\circ} \mathrm{C} .{ }^{1} \mathrm{H}$ NMR $\left(\mathrm{CDCl}_{3}\right): \delta 7.21(\mathrm{~m}, 1 \mathrm{H}), 7.36(\mathrm{~m}, 2 \mathrm{H}), 7.73(\mathrm{td}, 1 \mathrm{H}, J=8.0$ and 1.6), $7.81(\mathrm{~m}$, $4 \mathrm{H}), 8.64(\mathrm{~d}, 1 \mathrm{H}, J=5.0)$. These values are consistent with the literature. ${ }^{49}{ }^{13} \mathrm{C} \mathrm{NMR}\left(\mathrm{CDCl}_{3}\right): \delta 119.6$, $121.1,122.6(2 \mathrm{C}), 124.1,124.5,125.0,136.6,140.5,140.6,144.8,149.7,152.5$.

4-(2-Benzo[b]furyl)-2-chloropyrimidine (19). 19 was obtained according to the general procedure 2 from benzo[b]furan $(7,0.95 \mathrm{~g}, 0.88 \mathrm{~mL})$ and 2,4-dichloropyrimidine $(0.89 \mathrm{~g})$, and isolated after purification by chromatography on silica gel (eluent: $\mathrm{CH}_{2} \mathrm{Cl}_{2} / \mathrm{MeOH}$ : $100 / 0$ to $80 / 20$ ) as a pale yellow powder $(0.68 \mathrm{~g}, 49 \%) \cdot \mathrm{mp} 186{ }^{\circ} \mathrm{C} .{ }^{1} \mathrm{H} \mathrm{NMR}\left(\mathrm{CD}_{3} \mathrm{COCD}_{3}\right): \delta 7.37$ (br t, $\left.1 \mathrm{H}, J=7.8\right), 7.51$ (br t, $1 \mathrm{H}, J=$ 7.8), 7.69 (br d, $1 \mathrm{H}, J=7.8), 7.82$ (br d, $1 \mathrm{H}, J=7.8), 7.90(\mathrm{~s}, 1 \mathrm{H}), 7.97$ (d, 1H, $J=5.2), 8.86(\mathrm{~d}, 1 \mathrm{H}, J=$ 5.2). These values are consistent with the literature. ${ }^{50}{ }^{13} \mathrm{C} \mathrm{NMR}\left(\mathrm{CD}_{3} \mathrm{COCD}_{3}\right): \delta 110.9,112.4,115.4$, $123.5,124.7,128.1,128.7,152.2,156.5,158.6,161.8,162.1$.

Computations: All calculations were carried out with the Gaussian 03 program package. ${ }^{51}$ The 
molecular structures and harmonic vibrational frequencies were obtained at the B3LYP ${ }^{52}$ level with the basis set of Ahlrichs' SVP all-electron basis $\operatorname{set}^{53}$ for $\mathrm{Zn},{ }^{54}$ and $6-31+\mathrm{G}^{*} / 6-31 \mathrm{G}^{*}$ for the other atoms. Geometry optimization and vibrational analysis were performed at the same level. All stationary points were optimized without any symmetry assumptions, and characterized by normal coordinate analysis at the same level of theory (the number of imaginary frequencies, NIMAG, was 0 for minima and 1 for TSs). All the transition states structures and the reaction coordinates (Hessian eigenvectors with negative eigenvalues) were examined visually. The intrinsic reaction coordinate (IRC) method ${ }^{55}$ was used to track minimum energy paths from transition structures to the corresponding local minima.

\section{Acknowledgments}

We gratefully acknowledge the financial support of KAKENHI (Young Scientist (A), Houga, and Priority Area (No. 452 and 459) (to M.U.)), Région Bretagne (J. M. L. and A. S.), CNRS (A. S.) and GlaxoSmithKline (A. S.). We thank Stéphane Golhen and Thierry Roisnel for their contribution to this study. We thank CRMPO (Université de Rennes 1) for HRMS analysis. The calculations were performed on the RIKEN Super Combined Cluster (RSCC).

\section{Supporting Information Available}

General Procedures, Cartesian Coordinates and Total Electron Energies, copies of ${ }^{1} \mathrm{H}$ and ${ }^{13} \mathrm{C}$ NMR spectra for compounds $2,4,6,8,10,12,14,16,17,18$ and 19, as well as X-ray Diffraction Analysis of compound 17 including ORTEP figure and CIF file. This material is available free of charge via the Internet at http://pubs.acs.org.

\section{References and Footnotes}


(1) (a) Katritzky, A. R. Handbook of Heterocyclic Chemistry, $1^{\text {st }}$ ed.; Pergamon: New York, NY, 1985. (b)

Eicher, T.; Hauptmann, S.; Speicher, A. The Chemistry of Heterocycles, $2^{\text {nd }}$ ed., Wiley-VCH, 2003.

(2) Schlosser, M. Organometallics in Synthesis, $2^{\text {nd }}$ ed. (Ed.: Schlosser, M.), Wiley, 2002, Chapter I.

(3) Stanforth, S. P. Tetrahedron 1998, 54, 263-303.

(4) (a) Metzger, J.; Koether, B. Bull. Chem. Soc. Fr. 1953, 702-707. (b) Marxer, A.; Siegrist, M. Helv. Chim. Acta 1974, 57, 1988-2000. (c) Boga, C.; Del Vecchio, E.; Forlani, L.; Milanesi, L.; Todesco, P. E. J. Organomet. Chem. 1999, 588, 155-159. (d) Rao, P. D.; Littler, B. J.; Geier III, G. R.; Lindsey, J. S. J. Org. Chem. 2000, 65, $1084-1092$.

(5) (a) Eaton, P. E.; Lee, C.-H.; Xiong, Y. J. Am. Chem. Soc. 1989, 111, 8016-8018. (b) Schlecker, W.; Huth, A.; Ottow, E.; Mulzer, J. J. Org. Chem. 1995, 60, 8414-8416. (c) Schlecker, W.; Huth, A.; Ottow, E.; Mulzer, J. Liebigs Ann. 1995, 1441-1446. (d) Schlecker, W.; Huth, A.; Ottow, E.; Mulzer, J. Synthesis 1995, $1225-1227$. (e) Kondo, Y.; Yoshida, A.; Sakamoto, T. J. Chem. Soc., Perkin Trans. 1 1996, 2331-2332. (f) Shilai, M.; Kondo, Y.; Sakamoto, T. J. Chem. Soc., Perkin Trans. 1 2001, 442-444. (g) Ooi, T.; Uematsu, Y.; Maruoka, K. J. Org. Chem. 2003, 68, 4576-4578.

(6) (a) Awad, H.; Mongin, F.; Trécourt, F.; Quéguiner, G.; Marsais, F.; Blanco, F.; Abarca, B.; Ballesteros, R. Tetrahedron Lett. 2004, 45, 6697-6701. (b) Awad, H.; Mongin, F.; Trécourt, F.; Quéguiner, G.; Marsais, F. Tetrahedron Lett. 2004, 45, 7873-7877. (c) Krasovskiy, A.; Krasovskaya, V.; Knochel, P. Angew. Chem. 2006, 118, 3024-3027; Angew. Chem. Int. Ed. 2006, 45, 2958-2961. (d) Clososki, G. C.; Rohbogner, C. J.; Knochel, P. Angew. Chem. 2007, 119, 7825-7828; Angew. Chem. Int. Ed. 2007, 46, 7681-7684.

(7) (a) Kondo, Y.; Shilai, M.; Uchiyama, M.; Sakamoto, T. J. Am. Chem. Soc. 1999, 121, 3539-3540. See also: (b) Imahori, T.; Uchiyama, M.; Sakamoto, T.; Kondo, Y. Chem. Commun. 2001, 2450-2451; (c) Uchiyama, M.; Miyoshi, T.; Kajihara, Y.; Sakamoto, T.; Otani, Y.; Ohwada, T.; Kondo, Y. J. Am. Chem. Soc. 2002, 124, 85148515; (d) Uchiyama, M.; Matsumoto, Y.; Nobuto, D.; Furuyama, T.; Yamaguchi, K.; Morokuma, K. J. Am. Chem. Soc. 2006, 128, 8748-8750; (e) Uchiyama, M.; Kobayashi, Y.; Furuyama, T.; Nakamura, S.; Kajihara, Y.; Miyoshi, T.; Sakamoto, T.; Kondo, Y.; Morokuma, K. J. Am. Chem. Soc. 2007, 129, in press. 
(8) Al-ate base: (a) Uchiyama, M.; Naka, H.; Matsumoto, Y.; Ohwada, T. J. Am. Chem. Soc. 2004, 126, 10526-10527. (b) García-Álvarez, J.; Graham, D. V.; Kennedy, A. R.; Mulvey, R. E.; Weatherstone, S. Chem. Commun. 2006, 3208-3210. (c) Naka, H.; Uchiyama, M.; Matsumoto, Y.; Wheatley, A. E. H.; McPartlin, M.; Morey, J. V.; Kondo, Y. J. Am. Chem. Soc. 2007, 129, 1921-1930. Cu-ate base: (d) Usui, S.; Hashimoto, Y.; Morey, J. V.; Wheatley, A. E. H.; Uchiyama, M. J. Am. Chem. Soc. 2007, 129, in press.

(9) Knochel has just published a new mixed lithium-magnesium-zinc base, (TMP) ${ }_{2} \mathrm{Zn} \cdot 2 \mathrm{MgCl}_{2} \cdot 2 \mathrm{LiCl}$, that can be used stoichiometrically: Wunderlich, S. H.; Knochel, P. Angew. Chem. 2007, 119, 7829-7832; Angew. Chem. Int. Ed. 2007, 46, 7685-7688.

(10) (a) Barley, H. R. L.; Clegg, W.; Dale, S. H.; Hevia, E.; Honeyman, G. W.; Kennedy, A. R.; Mulvey, R. E. Angew. Chem. 2005, 117, 6172-6175; Angew. Chem. Int. Ed. 2005, 44, 6018-6021. (b) Clegg, W.; Dale, S. H.; Hevia, E.; Honeyman, G. W.; Mulvey, R. E. Angew. Chem. 2006, 118, 2430-2434; Angew. Chem. Int. Ed. 2006, 45, 2370-2374. (c) Clegg, W.; Dale, S. H.; Harrington, R. W.; Hevia, E.; Honeyman, G. W.; Mulvey, R. E. Angew. Chem. 2006, 118, 2434-2437; Angew. Chem. Int. Ed. 2006, 45, 2374-2377. (d) Clegg, W.; Dale, S. H.; Drummond, A. M.; Hevia, E.; Honeyman, G. W.; Mulvey, R. E. J. Am. Chem. Soc. 2006, 128, 7434-7435.

(11) For reviews, see: (i) Mulvey, R. E. Organometallics 2006, 25, 1060-1075; (b) Mulvey, R. E.; Mongin, F.; Uchiyama, M.; Kondo, Y. Angew. Chem. 2007, 119, 3876-3899; Angew. Chem. Int. Ed. 2007, 46, 3802-3824.

(12) (a) Schröder, R.; Schöllkopf, U.; Blume, E.; Hoppe, I. Liebigs Ann. Chem. 1975, 533-546. Reviews: (b) Gilchrist, T. L. Adv. Heterocycl. Chem. 1987, 41, 41-74; (c) Rewcastle, G. W.; Katritzky, A. R. Adv. Heterocycl. Chem. 1993, 56, 155-302; (d) Iddon, B. Heterocycles 1994, 37, 1321-1346.

(13) Kondo, Y.; Takazawa, N.; Yoshida, A.; Sakamoto, T. J. Chem. Soc., Perkin Trans. 1 1995, 1207-1208.

(14) Uchiyama, M.; Furuyama, T.; Kobayashi, M.; Matsumoto, Y.; Tanaka, K. J. Am. Chem. Soc. 2006, 128, 8404-8405.

(15) (a) Crowe, E.; Hossner, F.; Hughes, M. J. Tetrahedron 1995, 51, 8889-8900. (b) Hilf, C.; Bosold, F.; Harms, K.; Marsch, M.; Boche, G. Chem. Ber./Recl. 1997, 130, 1213-1221. (c) Boche, G.; Bosold, F.; Hermann, H.; Marsch, M.; Harms, K.; Lohrenz, J. C. W. Chem. Eur. J. 1998, 4, 814-817. At room temperature, a quick 
precipitation of the organozinc derivative was observed in THF.

(16) Concerning the synthesis of a lithium zincate from $\mathrm{ZnCl}_{2} \cdot \mathrm{TMEDA}$, see: Kjonaas, R. A.; Hoffer, R. K. $J$. Org. Chem. 1988, 53, 4133-4135.

(17) Isobe, M.; Kondo, S.; Nagasawa, N.; Goto, T. Chem. Lett. 1977, 679-682.

(18) Uchiyama, M.; Kameda, M.; Mishima, O.; Yokoyama, N.; Koike, M.; Kondo, Y.; Sakamoto, T. J. Am. Chem. Soc. 1998, 120, 4934-4946.

(19) The base prepared by successively adding 1 equiv of LiTMP and 1 equiv of TMEDA to a solution of dibutylzinc in hexane proved to be $\mathrm{Bu}_{2} \mathrm{Zn}(\mathrm{TMP}) \mathrm{Li}(\mathrm{TMEDA}) .{ }^{10 \mathrm{a}}$

(20) The use of tert-butyllithium was not attempted. Indeed, it has been shown that methyl and tert-butyl groups in $\mathrm{R}_{2} \mathrm{Zn}(\mathrm{TMP}) \mathrm{Li}$ behave similarly when deprotonation is concerned, the nature of these dummy ligands on $\mathrm{Zn}$ only influencing the stability of the generated metalated substrates. ${ }^{7 \mathrm{c}}$

(21) Compound 2 rapidly decomposes at room temperature.

(22) A 90\% yield of lithium 2-(isocyano)phenolate was estimated from the NMR spectrum using 1,2dimethoxyethane as internal standard.

(23) 15 and 5\% yields of lithium 2-(isocyano)phenolate and benzoxazole, respectively, were estimated from the NMR spectrum using 1,2-dimethoxyethane as internal standard. The 2-zincated species of benzoxazole which form (about $80 \%$ yield) are insoluble in the reaction mixture.

(24) (a) Putzer, M. A.; Neumuller, B.; Dehnicke, K. Z. Anorg. Allg. Chem. 1997, 623, 539-544. (b) Forbes, G. C.; Kennedy, A. R.; Mulvey, R. E.; Rodger, P. J. A. Chem. Commun. 2001, 1400-1401. (c) Clegg, W.; Forbes, G. C.; Kennedy, A. R.; Mulvey, R. E.; Liddle, S. T. Chem. Commun. 2003, 406-407.

(25) Mulvey, R. E. Chem. Commun. 2001, 1049-1056, spec. p. 1053.

(26) Seggio, A.; Lannou, M.-I.; Chevallier, F.; Nobuto, D.; Uchiyama, M.; Golhen, S.; Roisnel, T.; Mongin, F. Chem. Eur. J., DOI: 10.1002/chem.200700608. 
(27) An alternative mechanism is to assume that (TMP) ${ }_{3} \mathrm{ZnLi} \cdot \mathrm{TMEDA}$ is the catalytic deprotonating species. ${ }^{26}$

(28) (a) Metzger, J.; Koether, B. Bull. Chem. Soc. Fr. 1953, 708-709. (b) Pinkerton, F. H.; Thames, S. F. J. Heterocycl. Chem. 1971, 8, 257-259. (c) Jutzi, P.; Hoffmann, H. J. Chem. Ber. 1973, 106, 594-605. (d) Okuhara, K. J. Org. Chem. 1976, 41, 1487-1494.

(29) Jen, K.-Y.; Cava, M. P. J. Org. Chem. 1983, 48, 1449-1451.

(30) Zhang, H.; Larock, R. C. J. Org. Chem. 2002, 67, 7048-7056.

(31) Hasan, I.; Marinelli, E. R.; Lin, L;-C. C.; Fowler, F. W.; Levy, A. B. J. Org. Chem. 1981, 46, 157-164.

(32) (a) Alley, P. W.; Shirley, D. A. J. Am. Chem. Soc. 1958, 80, 6271-6274. (b) Marxer, A.; Siegrist, M. Helv. Chim. Acta 1974, 57, 1988-2000.

(33) Beraud, J.; Metzger, J. Bull. Chem. Soc. Fr. 1962, 2072-2074.

(34) The structure of $\mathbf{1 7}$ was unambiguously determined by X-ray diffraction analysis (see presented ORTEP figure in the Supporting Information).

(35) Clegg, W.; Dale, S. H.; Hevia, E.; Hogg, L. M.; Honeyman, G. W.; Mulvey, R. E.; O'Hara, C. T. Angew. Chem. 2006, 118, 6698-6700; Angew. Chem. Int. Ed. 2006, 45, 6548-6550.

(36) Armstrong, D. R.; Clegg, W.; Dale, S. H.; Graham, D. V.; Hevia, E.; Hogg, L. M.; Honeyman, G. W.; Kennedy, A. R.; Mulvey, R. E. Chem. Commun. 2007, 598-600.

(37) Schlosser, M. Angew. Chem. 2005, 117, 380-398; Angew. Chem. Int. Ed. 2005, 44, 376-393.

(38) These conditions proved convenient for the reaction between lithium 2-furylzincates and chloropyridines: Gauthier, D. R., Jr.; Szumigala, R. H., Jr.; Dormer, P. G.; Armstrong, J. D., III; Volante, R. P.; Reider, P. J. Org. Lett. 2002, 4, 375-378.

(39) Synthetic applications for the functionalization of diazines have been recently published: Seggio, A.; Chevallier, F.; Vaultier, M.; Mongin, F. J. Org. Chem. 2007, 72, 6602-6605. 
(40) Bayh, O.; Awad, H.; Mongin, F.; Hoarau, C.; Bischoff, L.; Trécourt, F.; Quéguiner, G.; Marsais, F.; Blanco, F.; Abarca, B.; Ballesteros, R. J. Org. Chem. 2005, 70, 5190-5196.

(41) Van den Hoven, B. G.; Alper, H. J. Am. Chem. Soc. 2001, 123, 1017-1022.

(42) Nicolas, Y.; Blanchard, P.; Levillain, E.; Allain, M.; Mercier, N.; Roncali, J. Org. Lett. 2004, 6, 273-276.

(43) Vallgårda, J.; Appelberg, U.; Arvidsson, L.-E.; Hjorth, S.; Svensson, B. E.; Hacksell, U. J. Med. Chem. 1996, 39, 1485-1493.

(44) Mongin, F.; Bucher, A.; Bazureau, J. P.; Bayh, O.; Awad, H.; Trécourt, F. Tetrahedron Lett. 2005, 46, 7989-7992.

(45) Roy, S.; Gribble, G. W. Tetrahedron Lett. 2005, 46, 1325-1328.

(46) Chen, W.; Cava, M. P. Tetrahedron Lett. 1987, 28, 6025-6026.

(47) Sakamoto, T.; Shiga, F.; Uchiyama, D.; Kondo, Y.; Yamanaka, H. Heterocycles 1992, 33, 813-818.

(48) Dondoni, A.; Mastellani, A. R.; Medici, A.; Negrini, E.; Pedrini, P. Synthesis 1986, 757-760.

(49) Thomas, S. W., III; Venkatesan, K.; Müller, P.; Swager, T. M. J. Am. Chem. Soc. 2006, 128, 1664116648.

(50) Strekowski, L.; Harden, M. J.; Grubb, W. B., III; Patterson, S. E.; Czarny, A.; Mokrosz, M. J.; Cegla, M. T.; Wydra, R. L. J. Heterocycl. Chem. 1990, 27, 1393-1400.

(51) Gaussian 03, revision B.04; Frisch, M. J.; Trucks, G. W.; Schlegel, H. B.; Scuseria, G. E.; Robb, M. A.; Cheeseman, J. R.; Montgomery, J. A., Jr.; Vreven, T.; Kudin, K. N.; Burant, J. C.; Millam, J. M.; Iyengar, S. S.; Tomasi, J.; Barone, V.; Mennucci, B.; Cossi, M.; Scalmani, G.; Rega, N.; Petersson, G. A.; Nakatsuji, H.; Hada, M.; Ehara, M.; Toyota, K.; Fukuda, R.; Hasegawa, J.; Ishida, M.; Nakajima, T.; Honda, Y.; Kitao, O.; Nakai, H.; Klene, M.; Li, X.; Knox, J. E.; Hratchian, H. P.; Cross, J. B.; Adamo, C.; Jaramillo, J.; Gomperts, R.; Stratmann, R. E.; Yazyev, O.; Austin, A. J.; Cammi, R.; Pomelli, C.; Ochterski, J. W.; Ayala, P. Y.; Morokuma, K.; Voth, G. A.; Salvador, P.; Dannenberg, J. J.; Zakrzewski, V. G.; Dapprich, S.; Daniels, A. D.; Strain, M. C.; Farkas, O.; 
Malick, D. K.; Rabuck, A. D.; Raghavachari, K.; Foresman, J. B.; Ortiz, J. V.; Cui, Q.; Baboul, A. G.; Clifford, S.; Cioslowski, J.; Stefanov, B. B.; Liu, G.; Liashenko, A.; Piskorz, P.; Komaromi, I.; Martin, R. L.; Fox, D. J.; Keith, T.; Al-Laham, M. A.; Peng, C. Y.; Nanayakkara, A.; Challacombe, M.; Gill, P. M. W.; Johnson, B.; Chen, W.; Wong, M. W.; Gonzalez, C.; Pople, J. A.; Gaussian, Inc.: Pittsburgh, PA, 2003.

(52) (a) Becke, A. D. Phys. Rev. 1988, A38, 3098-3100. (b) Becke, A. D. J. Chem. Phys. 1993, 98, 1372-1377. (c) Becke, A. D. J. Chem. Phys. 1993, 98, 5648-5652. (d) Lee, C.; Yang, W.; Parr, R. G. Phys. Rev. 1988, B37, $785-788$.

(53) Schäfer, A.; Horn, H.; Ahlrichs, R. J. Chem. Phys. 1992, 97, 2571-2577.

(54) Ahlrichs, R.; May, K. Phys. Chem. Chem. Phys. 2000, 2, 943-945.

(55) (a) Fukui, K. Acc. Chem. Res. 1981, 14, 363-368; (b) Gonzalez, C.; Schlegel, H. B. J. Chem. Phys. 1989, 90, 2154-2161; (c) Gonzalez, C.; Schlegel, H. B. J. Phys. Chem. 1990, 94, 5523-5527. 